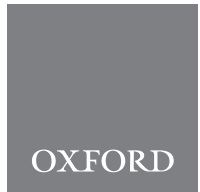

\title{
STUDIES
}

\section{Bryophyte cover and richness decline after 18 years of experimental warming in alpine Sweden}

\author{
Juha M. Alatalo ${ }^{1^{*}}$, Annika K. Jägerbrand², Mohammad Bagher Erfanian², \\ Shengbin Chen ${ }^{4}$, Shou-Qin Sun ${ }^{5}$ and Ulf Molau ${ }^{6}$
}

${ }^{1}$ Environmental Science Center, Qatar University, PO Box 2713, Doha, Qatar, ${ }^{2}$ Department of Environmental and Biosciences, School of Business, Innovation and Sustainability, Halmstad University, PO Box 823, SE-301 18 Halmstad, Sweden, ${ }^{3}$ Quantitative Plant Ecology and Biodiversity Research Lab., Department of Biology, Faculty of Science, Ferdowsi University of Mashhad, Mashhad, 9177948974, Iran, ${ }^{4}$ College of Ecology and Environment, Chengdu University of Technology, Chengdu 610041, China, ${ }^{5}$ Institute of Mountain Hazards and Environment, Chinese Academy of Science, Chengdu 610059, China, ${ }^{6}$ Department of Biological and Environmental Sciences, University of Gothenburg, PO Box 461, SE-405 30 Gothenburg, Sweden

*Corresponding author's e-mail address: alatalojm@gmail.com

Populations \& Communities. Chief Editor: Jean Burns

Associate Editor: Jean Burns

\begin{abstract}
Climate change is expected to affect alpine and Arctic tundra communities. Most previous long-term studies have focused on impacts on vascular plants, this study examined impacts of long-term warming on bryophyte communities. Experimental warming with open-top chambers (OTCs) was applied for 18 years to a mesic meadow and a dry heath alpine plant community. Species abundance was measured in 1995, 1999, 2001 and 2013. Species composition changed significantly from original communities in the heath, but remained similar in mesic meadow. Experimental warming increased beta diversity in the heath. Bryophyte cover and species richness both declined with long-term warming, while Simpson diversity showed no significant responses. Over the 18-year period, bryophyte cover in warmed plots decreased from $43 \%$ to $11 \%$ in heath and from $68 \%$ to $35 \%$ in meadow (75\% and $48 \%$ decline, respectively, in original cover), while richness declined by $39 \%$ and $26 \%$, respectively. Importantly, the decline in cover and richness first emerged after 7 years. Warming caused significant increase in litter in both plant communities. Deciduous shrub and litter cover had negative impact on bryophyte cover. We show that bryophyte species do not respond similarly to climate change. Total bryophyte cover declined in both heath and mesic meadow under experimental long-term warming (by $1.5-3{ }^{\circ} \mathrm{C}$ ), driven by general declines in many species. Principal response curve, cover and richness results suggested that bryophytes in alpine heath are more susceptible to warming than in meadow, supporting the suggestion that bryophytes may be less resistant in drier environments than in wetter habitats. Species loss was slower than the decline in bryophyte abundance, and diversity remained similar in both communities. Increased deciduous shrub and litter cover led to decline in bryophyte cover. The non-linear response to warming over time underlines the importance of long-term experiments and monitoring.
\end{abstract}

Keywords: Climate change; global warming; mosses; plant-climate interactions; plant litter, plant-plant interactions; species richness. 


\section{Introduction}

Arctic and alpine ecosystems are likely to experience a faster rate of warming than the global average (Chapin et al. 1995; Mack et al. 2004; IPCC 2013). Climate change is therefore likely to cause shifts in the range and relative abundance of Arctic/ alpine organisms. Bryophytes in particular are predicted to be vulnerable to climate change, as many have low-temperature optima for photosynthesis and a narrow range of suitable temperatures for net photosynthetic gain (He et al. 2016). A longterm study (spanning the periods 1850-1939 and 1940-99) on the relative abundance of bryophytes based on biological collections across all major habitat types in Switzerland found that 16 species declined, four showed an increase and seven remained stable (Hofmann et al. 2007).

Bryophytes in Arctic and alpine regions are important in terms of biodiversity, typically exhibiting almost double the species richness of vascular plants in the Arctic (Matveyeva and Chernov 2000; Bahuguna et al. 2016; Mateo et al. 2016). Similarly, bryophytes are important contributors to cover and biomass (Longton 1984; Cornelissen et al. 2007). In term of biomass, bryophytes have been reported to contribute up to $91 \%$ of above-ground biomass in a sedge-moss meadow in Western Taimyr, Siberia (Wielgolaski 1972), and an average of $38 \%$ of above-ground biomass at a range of tundra sites (Wielgolaski 1972; Oechel and Sveinbjörnsson 1978). In a study in China, bryophyte cover was found to increase from $17.4 \%$ to $95.6 \%$ along an altitudinal transect from 2000 to $4200 \mathrm{~m}$ above sea level (a.s.l.) in the Gongga Mountains (Sun et al. 2013). In addition, bryophytes are important contributors to ecosystem services, while some host nitrogen-fixing bacteria and provide nitrogen inputs to ecosystems (During and Van Tooren 1990; Turetsky 2003). They also act as the major food source for some invertebrates (Collembola, cranefly, various species of Diptera) and vertebrates (Soay sheep, reindeer, barnacle geese) (Herbert and Prins 1982; Crafford and Chown 1991; Hodkinson et al. 1994; Smith et al. 2001; Glime 2006; Imada and Kato 2016). This is particularly common in cold environments (Herbert and Prins 1982). Despite this, vascular plants rather than bryophytes have been the focus of most climate change studies to date (Arft et al. 1999; Walker et al. 2006; Elmendorf et al. 2012a; 2012b; Alatalo et al. 2014b; Dumais et al. 2014; Wheeler et al. 2016; Zhang et al. 2016).

Most previous studies have shown that bryophyte biomass and/or cover is sensitive to long-term warming (8-20 years) at alpine and Arctic sites (Chapin et al. 1995; Wahren et al. 2005; Elmendorf et al. 2012a; Lang et al. 2012; Sistla et al. 2013). However, an increase in bryophyte cover has also been reported (Hudson and Henry 2010). Shorter-term studies (2-7 years) report contrasting results more frequently (Press et al. 1998; Jägerbrand et al. 2003; Bates et al. 2005; Klanderud 2008; Lang et al. 2009; Alatalo et al. 2014a; Koncz et al. 2018). The response of bryophytes to climate warming may also be context-specific, depending on potential competition from vascular plants (Molau and Alatalo 1998; Jägerbrand et al. 2012) and the origin of the sampled population, as shown in an ex situ experiment in Japan (Jägerbrand et al. 2014). Moreover, most studies provide summaries of cover/biomass of whole bryophyte communities (Sistla et al. 2013), while only a few have collected species-level data to study the impact on species or bryophyte diversity and richness (Molau and Alatalo 1998; Jägerbrand et al. 2003; Wahren et al. 2005; Klanderud 2008; Klanderud and Totland 2008; Lang et al. 2012; Alatalo et al. 2014a, 2015a; Sun et al. 2017). Climate change can also have indirect effects on bryophyte communities. Several studies have reported increasing shrubification of alpine and Arctic tundra ecosystems, a process that is predicted to increase in future due to climate change (Jägerbrand et al. 2009; Myers-Smith et al. 2011; Maliniemi et al. 2018; MyersSmith and Hik 2018; Vowles and Björk 2019). Shrubification could potentially affect bryophyte communities, although previous studies have found inconsistent relationships between bryophytes and vascular plant abundance (Lang et al. 2012). Another question is whether species loss is delayed following a decline in abundance of bryophytes. It is not known whether species loss will occur rapidly, indicating that 'rare' species are lost initially, or at a longer interval after the decline in bryophyte abundance.

In the present study, bryophyte communities were examined following 18 years of experimental warming in two contrasting alpine sub-Arctic plant communities (mesic meadow and dry heath) in northern Sweden. The hypotheses tested were that: (i) bryophyte community composition is altered by longterm warming; (ii) bryophyte cover, richness and diversity are decreased by long-term warming; (iii) bryophyte cover, richness and diversity are negatively related to deciduous shrub cover and litter cover; and (iv) the negative impacts of warming are greater for mesic meadow, with its more developed vascular plant community, than for heath, with its sparser vascular plant community.

\section{Materials and Methods}

\section{Study area}

The study was conducted at Latnjajaure field station, which is located in the Latnjavagge valley $\left(68^{\circ} 21^{\prime} \mathrm{N}, 18^{\circ} 29^{\prime} \mathrm{E} ; 1000 \mathrm{~m}\right.$ a.s.l.) in northern Sweden. The climate at the site is classified as sub-Arctic (Polunin 1951), with snow cover for 7-8 months of the year, cool summers and relatively mild, snow-rich winters. The growing season starts in late May and ends in early September (Molau et al. 2005). Mean annual air temperature in the study period (1993-2013) ranged from -0.76 to $-2.92{ }^{\circ} \mathrm{C}$ (Alatalo et al. 2017a). Mean monthly temperature was highest in July, ranging from $5.9^{\circ} \mathrm{C}$ in 1995 to $13.1{ }^{\circ} \mathrm{C}$ in 2013 (Alatalo et al. 2017a). Mean annual precipitation during the period was $846 \mathrm{~mm}$, but in individual years it ranged from a low of $607 \mathrm{~mm}$ (1996) to a high of $1091 \mathrm{~mm}$ (2003) (Alatalo et al. 2017a). Climate data were collected throughout the year at the weather station at Latnjajaure field station, with hourly means, maxima and minima recorded (Molau and Alatalo 1998). Physical conditions in the valley soils vary from dry to wet, and from acidic to baserich, with an associated variation in plant communities (Molau and Alatalo 1998; Lindblad et al. 2006; Björk et al. 2007; Alatalo et al. 2014b, 2017a). The mesic meadow community has a more well-developed vegetation cover (67\% canopy cover) (Alatalo et al. 2017), dominated by Carex vaginata, C. bigelowii, Festuca ovina, Salix reticulata, S. polaris, Cassiope tetragona, Bistorta vivipara and Thalictrum alpinum (Molau and Alatalo 1998; Alatalo et al. 2014b). The more sparsely vegetated heath community (54\% canopy cover) (Alatalo et al. 2017a) is dominated by Betula nana, Salix herbacea and Calamagrostis lapponica (Molau and Alatalo 1998; Alatalo et al. 2015b). Species richness and diversity in the heath and meadow experimental plots have been shown to be similar to those in the natural bryophyte communities in other vegetation types in the Latnjajaure area, such as dry heath, patterned heath, heath snowbed, mesic meadow, moist meadow and medium-rich fen (Jägerbrand et al. 2006). 


\section{Experimental design and measurements}

The 18-year study ranged from 1995 to 2013 . Sampling in control and experimental (i.e. warming) plots was conducted in 1995, 1999, 2001 and 2013. At the start of the experiment, there were eight control plots and four plots with experimental warming in each plant community. However, not all initial control plots could be identified in 2013 , so measurements were only made in four control and four experimental warming plots in each community in that year. Thus, for 2013, data from only four plots per treatment were used, while for 1995-2001, data from eight control plots were used. At the start of the experiment in July 1995, 12 plots $(1 \mathrm{~m} \times 1 \mathrm{~m})$ with homogenous vegetation cover were marked out in both the alpine mesic meadow and the heath plant communities, and randomly assigned to treatments (control, experimental warming) in a pairwise design. Experimental warming was applied using hexagonal open-top chambers (OTCs), which were left in place on plots with warming treatment all year-around. In the initial years (1995-98), the temperature in the control and OTC plots was monitored for the entire year, in all 3 years, with Delta ${ }^{\mathrm{TM}}$ and Tinytag ${ }^{\text {TM }}$ loggers. As found in other studies (Marion et al. 1997; Molau and Alatalo 1998; Hollister and Webber 2000), OTCs increased the air temperature by $1.5-3^{\circ} \mathrm{C}$ compared with control plots with ambient temperature. It has also been shown that OTCs decrease canopy moisture (Hollister and Webber 2000), causing earlier snowmelt and prolonging the growing season (Molau and Alatalo 1998; Hollister and Webber 2000).

The species present in the plots [see Supporting InformationTable S1] were identified in the field or with the help of experienced bryophyte taxonomist Sven Franzén. Nomenclature for bryophyte species was retrieved from the literature (The Plant List 1.12013 ; USDA, NRCS 2020). Coverage of each bryophyte species was assessed using a $1 \mathrm{~m} \times 1 \mathrm{~m}$ frame with 100 grid points (hereafter 'hits') (Walker 1996) in the middle of the growing season in 1995, 1999 (after 5 years), 2001 (after 7 years) and 2013 (after 18 years). Due to their hexagonal shape, the OTCs reduced the number of hits per plot to 77-87, and thus warmed plots had fewer hits than control plots. To enable comparison despite unequal sample size, the relative change over time in vegetation response for each treatment was calculated, as suggested by Kent (2011). The relative change was then used as the response variable in the statistical analyses (Kent 2011). To ensure accuracy and reproducibility, the same grid frame was used for each measurement, and fixed points at the corner of each plot allowed the frame to be replaced in the same positions within the plot on each measuring occasion. This method has been shown to be accurate in detecting changes in tundra vegetation (May and Hollister 2012).

\section{Statistical analyses}

All statistical tests were conducted using R (R Core Team 2019).

\section{Species composition}

Principal response curves. To test the hypothesis that bryophyte community composition is altered by long-term warming, we applied principal response curves (PRCs) (van den Brink et al. 2009) to the species composition (with bryophyte cover as an abundance measure) matrix data for the years 1995, 1999, 2001 and 2013. Because of unbalanced data for 2013, we opted not to conduct a formal permutation test. The prc function in the vegan package was used for this analysis (Oksanen et al. 2017; Oksanen 2018).

Analysis of similarity. To test whether the species composition in control and warming plots differed significantly in 1995 and
2013, we used analysis of similarity (ANOSIM) with 999 time permutations. We also tested the difference between 1995 and 2013 control and warming plots using ANOSIM. The species composition matrices used in ANOSIMs were the same as those of PRC. The differences between 1995 and 1999, and between 1995 and 2001, have been reported previously (reference anonymized). Separate ANOSIMs were performed for each type of vegetation. Therefore, eight ANOSIMs were performed. The anosim function in the vegan package was used for this analysis (Oksanen et al. 2017; Oksanen 2018).

\section{Species diversity and cover}

To test the hypothesis that bryophyte cover, richness and diversity are decreased by long-term warming, we conducted the following three calculations and analyses.

\section{Bryophyte alpha diversity and cover}

Bryophyte cover, species richness and diversity community parameters were calculated for comparison of warming and control plots in 1995-2013 for each vegetation type. From the point-frame data, the number of hits was summed up within each plot to produce plot-level abundance measures for each species. These values were used to calculate plotwise total bryophyte cover, species richness and Simpson's diversity index D (Simpson 1949). Simpson's diversity index was chosen since it is reliable even when the sample size is small (Mouillot and Lepretre 1999). In addition, it considers the diversity at the level of dominant species. The species richness metric considers the diversity of species without giving weight to the species (i.e. without considering their abundances), but Simpson's diversity index (hereafter called 'diversity') gives higher weight to dominant species and rare species do not change its value. The calculated values were then transformed to relative change (ratio) for each individual plot for the whole period of the study (1995-2013), with 1995 data for each plot taken as the starting value. Relative change was used as the response variable because the number of hits per plot differed between treatments and because plots differed in their starting values of cover, richness and species composition. Data on bryophyte cover, species richness and diversity were checked for normality assumptions using Q-Q plots, and for homogeneity of variance using the Bartlett test. The $\mathrm{Q}-\mathrm{Q}$ plots revealed that species richness, cover and diversity data were not normally distributed. Therefore, the Mann-Whitney U-test, a robust non-parametric test, was used to examine the effect of the experimental warming treatment on the relative change between all years in bryophyte cover, richness and diversity for the heath and meadow ecosystems. Friedman tests were used to compare these factors between years in each control and warming plot. Finally, boxplots showing changes in bryophyte cover, richness and diversity for the heath and meadow vegetation types were created using the ggplot2 package (Wickham 2009). These boxplots were calculated for both relative and absolute values, to better explain the variation in the data.

\section{Beta diversity}

To test whether climate change affected beta diversity (i.e. variation in species composition in the plots) within treatments for the two community types studied, beta diversity was calculated for each year. To do so, a separate Hellinger distance matrix was created for control and warming plots in each year for each plant community, using the vegdist function in the vegan package (Oksanen et al. 2017; 
Oksanen 2018). The Hellinger distance approach was chosen because it is not affected by double zeros (Erfanian et al. 2019). The results were relativized with the same procedure as described above. The Mann-Whitney and Friedman tests were used for statistical comparisons. Boxplots showing variation in beta diversity for the heath and meadow vegetation types were created.

Relationships between bryophyte richness and cover, deciduous shrub cover and litter cover

To assess changes in shrubification (here deciduous shrubs), which is hypothesized to have an impact on bryophyte communities, we used the same calculations and statistical tests as described above for bryophyte diversity and cover. To test the hypothesis that bryophyte cover and richness are negatively related to deciduous shrub and litter cover, we used multiple linear regression analysis. We regressed bryophyte species richness and cover against the cover of deciduous shrubs and litter and their interaction. We did not include site (i.e. meadow and heath), treatment (control and warming) and year as explanatory variables in the analysis, because they were confounder variables that affected both response variables (i.e. species richness and bryophytes cover) and explanatory variables (i.e. deciduous shrubs cover and litter cover) of this regression.

\section{Results}

\section{Species composition}

Principal response curve. The PRC for the heath and meadow vegetation types, with 1995 data (i.e. both control and warming plots) used as reference, showed the response over time of the communities to experimental warming. For the heath vegetation type, the species composition of control and warming plots was initially relatively similar and remained similar until 2001, after which differences emerged (Fig. 1). In PRC, species weights revealed the relative contribution of individual species to the community response. Species with positive weights increased more in the warming plots than in the control plots over time. In the heath vegetation type, Ptilidium ciliare showed an abundance increase in warming plots relative to control plots over time, whereas Kiaeria starkei and Gymnomitrion concinnatum abundance in warming plots was reduced compared with that in the control plots (Fig. 1). The PRC for the meadow, with 1995 used as reference, indicated that the species composition of the warming and control plots was relatively different at the start of the experiment, but between 2001 and 2013 it became more similar (Fig. 1). Sphagnum capillifolium and P. ciliare showed the greatest increase in abundance in warming plots compared with control plots, while Hylocomium splendens and Polytrichum alpinum showed the
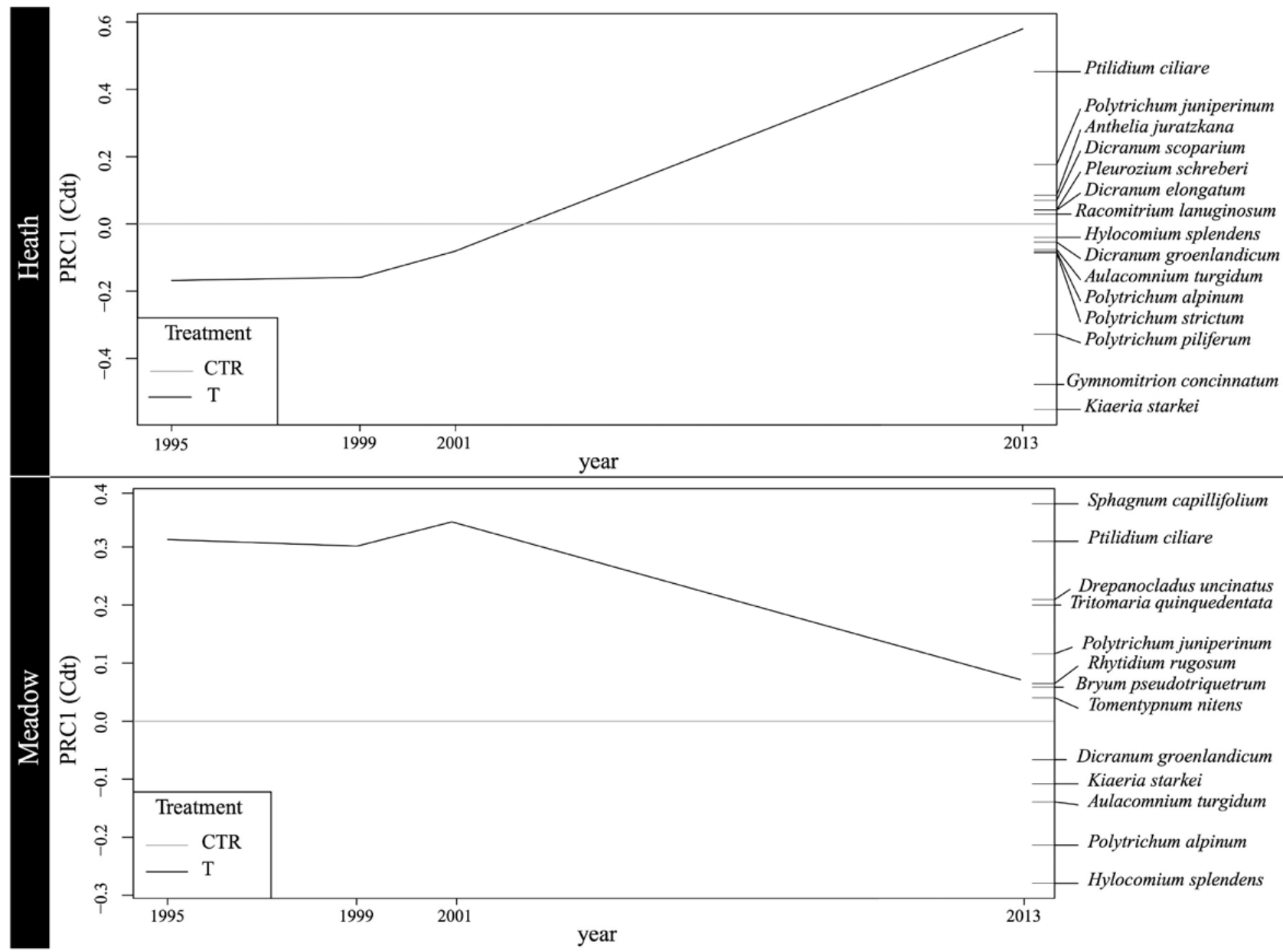

Figure 1. Principal response curve showing the effect of warming treatment over time on presence of bryophyte species in heath and meadow vegetation at Latnjajaure, northern Sweden. CTR = control plots; $\mathrm{T}$ = warmed plots (OTCs). The zero line indicates control plots. 
greatest decrease in abundance in warming plots compared with control plots (Fig. 1).

Analysis of similarity. Analysis of similarities indicated that species composition had changed significantly in the heath (but not in the meadow) in both the control plots $(P=0.002)$ and warmed plots $(P=0.029)$ after 18 years, but there was no difference between control and warmed plots at the start or end of the study period in either heath or meadow (Table 1).

\section{Bryophyte cover, richness and species diversity}

Bryophyte cover had declined by around $75 \%$ in the heath and $50 \%$ in the meadow after 18 years of experimental warming (Tables 2 and 3; Fig. 2: see Supporting Information-Fig. S1). In contrast, these effects of warming were not significant after 7 years of treatments (Table 2). In the control treatments, bryophyte cover showed non-significant and inconsistent changes (Fig. 2).

Bryophyte richness declined significantly in response to experimental warming in the heath $(P=0.028)$, while it did not change significantly in the meadow (Table 2; Fig. 2: see Supporting Information-Fig. S1). After 18 years of experimental warming, richness had declined by around $40 \%$ in the heath and $25 \%$ in the meadow (Fig. 2). Comparing the variation in relative values of species richness from 1995 to 2013 in both heath and meadow, warming plots showed a non-significant tendency for decreased species richness (Table 3; Fig. 2: see Supporting Information-Fig. S1). The decline in bryophyte species richness accelerated after 2001 in both communities, but was not significant in the meadow (Fig. 2).

Although a decreasing trend was observed in warming plots (Fig. 2), bryophyte diversity did not show any significant response to experimental warming in either the heath or the meadow (Tables 1-3: see Supporting Information-Fig. S1).

In the heath, there was a non-significant tendency for increased beta diversity in the warmed plots, and there were no significant differences between the years in either control or warming plots (Tables 2 and 3; Fig. 2: see Supporting Information-Fig. S1). In the meadow, there was a significant difference in beta diversity between warmed and control plots in 2001 (Table 2), and warmed plots had significantly higher beta diversity 2001 than 1999 (Table 3; Fig. 2: see Supporting Information-Fig. S1).

Litter cover in both heath and meadow plots showed contrasting responses in control and warming plots. Warmed plots in the heath had significantly higher litter cover in 2001 and 2013 (Table 2). In the heath, litter cover decreased significantly after 18 years in the control plots, while there was no change in the meadow (Table 3; Fig. 2: see Supporting InformationFig. S1). In warmed plots, litter cover significantly increased over time in both the heath (from around 22 to $58 \%$ cover) and meadow (from around 19 to $45 \%$ ) (Tables 2 and 3; Fig. 2: see Supporting Information-Fig. S1).

Deciduous shrub cover increased significantly in response to warming in the heath (Table 2; Fig. 2: see Supporting Information-Fig. S1). No significant differences were observed between the years in control plots in the heath vegetation (Table 3). However, in warmed plots, deciduous shrubs increased over time (Table 3; Fig. 2). In the meadow, there was no significant difference between control and warmed plots (Table 2). However, in both control and warmed plots deciduous shrubs increased over time, with a $300 \%$ increase in shrub cover after 18 years in warmed plots (Table 3; Fig. 2: see Supporting Information-Fig. S1).

Relationships between bryophyte richness and cover, deciduous shrub cover and litter cover

In the multiple linear regression that was calculated to predict bryophytes cover based on the deciduous shrubs and litter cover, a significant regression equation was found $(F(3,84)=36.69$, $P$-value $<0.000)$, with an adjusted $R^{2}$ of 0.552 . The predicted

Table 1. Analysis of similarity results comparing differences in bryophyte species composition in control (CTR) and warming (Temp) plots in meadow and heath vegetation at Latnjajaure, northern Sweden, in 1995, 2013 and 1995 vs. 2013. Values in bold represent significance at 0.05 level.

\begin{tabular}{lllll}
\hline Vegetation type & Year & Treatment & P-value \\
\hline Meadow & 1995 & CTR vs. Temp & 0.084 & 0.2353 \\
Meadow & 2013 & CTR vs. Temp & 0.386 & 0.02083 \\
Meadow & 1995 vs. 2013 & CTR & 0.521 & -0.0294 \\
Meadow & 1995 vs. 2013 & Temp & 0.796 & -0.156 \\
Heath & 1995 & CTR vs. Temp & 0.371 & 0.0275 \\
Heath & 2013 & CTR vs. Temp & 0.093 & 0.2812 \\
Heath & 1995 vs. 2013 & CTR & 0.002 & 0.6783 \\
Heath & 1995 vs. 2013 & Temp & 0.029 & 0.7344 \\
\hline
\end{tabular}

Table 2. Probability $(P)$ values in Mann-Whitney tests on the effects of warming on the measured variables. Values in bold numbers are statistically significant $(\alpha=0.05)$. C $=$ control; $W=$ warming.

\begin{tabular}{|c|c|c|c|c|c|c|c|}
\hline $\begin{array}{l}\text { Vegetation } \\
\text { type }\end{array}$ & Year & $\begin{array}{l}\text { Bryophyte } \\
\text { cover }\end{array}$ & $\begin{array}{l}\text { Species } \\
\text { richness }\end{array}$ & Diversity & $\begin{array}{l}\text { Beta } \\
\text { diversity }\end{array}$ & $\begin{array}{l}\text { Litter } \\
\text { cover }\end{array}$ & $\begin{array}{l}\text { D. shrubs } \\
\text { cover }\end{array}$ \\
\hline \multirow[t]{4}{*}{ Heath } & 1995 & 0.683 & 0.548 & 0.933 & 0.581 & 0.932 & 0.933 \\
\hline & 1999 & 0.368 & 0.9 & 0.808 & 0.188 & 0.05 & 0.307 \\
\hline & 2001 & 0.074 & 0.347 & 0.683 & 0.06 & $0.008(\mathrm{~W})$ & 0.734 \\
\hline & 2013 & $0.029(\mathrm{C})$ & $0.028(\mathrm{C})$ & 0.114 & 0.181 & $0.029(\mathrm{~W})$ & $0.029(\mathrm{~W})$ \\
\hline \multirow[t]{4}{*}{ Meadow } & 1995 & 0.933 & 0.667 & 0.683 & 0.676 & 0.932 & 0.99 \\
\hline & 1999 & 0.933 & 0.146 & 0.808 & 0.912 & 0.393 & 0.99 \\
\hline & 2001 & 0.154 & 0.098 & 0.683 & $0.029(\mathrm{~W})$ & 0.668 & 0.99 \\
\hline & 2013 & 0.029 (C) & 0.457 & 0.486 & 0.234 & $0.029(\mathrm{~W})$ & 0.052 \\
\hline
\end{tabular}


Table 3. Friedman test results on comparing response variables measured for control and warming plots between measurement years. Periods within brackets are significantly different from each other. Dec. = deciduous; ns = non-significant.

\begin{tabular}{|c|c|c|c|}
\hline $\begin{array}{l}\text { Vegetation } \\
\text { type }\end{array}$ & Treatment & $\begin{array}{l}\text { Measured } \\
\text { variable }\end{array}$ & $\begin{array}{l}\text { Friedman test + } \\
\text { post hoc results }\end{array}$ \\
\hline Heath & Control & $\begin{array}{l}\text { Species } \\
\text { richness }\end{array}$ & ns \\
\hline Heath & Warming & $\begin{array}{l}\text { Species } \\
\text { richness }\end{array}$ & ns \\
\hline Meadow & Control & $\begin{array}{l}\text { Species } \\
\text { richness }\end{array}$ & ns \\
\hline Meadow & Warming & $\begin{array}{l}\text { Species } \\
\text { richness }\end{array}$ & ns \\
\hline Heath & Control & Diversity & ns \\
\hline Heath & Warming & Diversity & ns \\
\hline Meadow & Control & Diversity & ns \\
\hline Meadow & Warming & Diversity & ns \\
\hline Heath & Control & $\begin{array}{l}\text { Beta } \\
\text { diversity }\end{array}$ & ns \\
\hline Heath & Warming & $\begin{array}{l}\text { Beta } \\
\text { diversity }\end{array}$ & ns \\
\hline Meadow & Control & $\begin{array}{l}\text { Beta } \\
\text { diversity }\end{array}$ & ns \\
\hline Meadow & Warming & $\begin{array}{l}\text { Beta } \\
\text { diversity }\end{array}$ & (1995-2001) \\
\hline Heath & Control & $\begin{array}{l}\text { Bryophyte } \\
\text { cover }\end{array}$ & ns \\
\hline Heath & Warming & $\begin{array}{l}\text { Bryophyte } \\
\text { cover }\end{array}$ & (1995-2013) \\
\hline Meadow & Control & $\begin{array}{l}\text { Bryophyte } \\
\text { cover }\end{array}$ & ns \\
\hline Meadow & Warming & $\begin{array}{l}\text { Bryophytes } \\
\text { cover }\end{array}$ & (1995-2001) \\
\hline Heath & Control & $\begin{array}{l}\text { Dec. shrub } \\
\text { cover }\end{array}$ & ns \\
\hline Heath & Warming & $\begin{array}{l}\text { Dec. shrub } \\
\text { cover }\end{array}$ & $\begin{array}{l}\text { (1995-99), } \\
\quad(1995-2013)\end{array}$ \\
\hline Meadow & Control & $\begin{array}{l}\text { Dec. shrub } \\
\text { cover }\end{array}$ & $\begin{array}{l}\text { (1995-99), (1995- } \\
\text { 2001), (1995-2013) }\end{array}$ \\
\hline Meadow & Warming & $\begin{array}{l}\text { Dec. shrub } \\
\text { cover }\end{array}$ & (1995-2013) \\
\hline Heath & Control & Litter cover & (1995-2013) \\
\hline Heath & Warming & Litter cover & (1995-2013) \\
\hline Meadow & control & Litter cover & ns \\
\hline Meadow & warming & Litter cover & $\begin{array}{l}(1999-2001) \\
\quad(1999-2013)\end{array}$ \\
\hline
\end{tabular}

bryophytes cover was equal to $77.883-0.774$ (deciduous shrubs cover) - 1.112 (litter cover), where both deciduous shrubs and litter cover are measured in percent. Bryophytes cover decreased $0.774 \%$ for each percent of deciduous shrubs cover and $1.112 \%$ for each percent of litter cover. Deciduous shrubs cover increased the negative effects of litter cover with a coefficient of 0.013 . Both explanatory variables and their interaction were significant, with higher values of bryophytes cover generally found in the lowest deciduous shrubs/litter cover values (Fig. 3).

The multiple linear regression for bryophyte species richness was significant. A significant regression equation was found $(F(3,84)=3.279, P=0.025)$, with an adjusted $R^{2}$ value of 0.072 . The predicted bryophyte species richness was equal to $5.717+0.028$ (deciduous shrub cover) +0.007 (litter cover), where both deciduous shrub and litter cover are measured in percent. Bryophytes species richness increased by $0.027 \%$ for each $1 \%$ increase in deciduous shrub cover and by $0.007 \%$ for each $1 \%$ increase in litter cover. Deciduous shrub cover decreased the positive effects of litter cover, with a coefficient of 0.001 . Only the interaction was significant. However, although there was a significant regression, the $R^{2}$ values showed that model performance was poor. The 3D graph revealed no observable pattern of species richness based on deciduous shrub and litter cover (Fig. 3).

\section{Discussion}

This study examined the impact of 18 years of experimental warming on bryophyte communities in an alpine heath and an alpine meadow community in sub-Arctic northern Sweden. Most previous studies on the potential impact of climate change on bryophytes have focused on cover/biomass (Sistla et al. 2013), but this study we examined the potential impact of warming on bryophyte community composition. We determined changes in species composition, species richness and diversity, and assessed the potential impact of increased shrub encroachment and litter cover on bryophyte cover and richness. We found partial support for three of our four initial hypotheses. (i) As hypothesized, bryophyte community composition was altered by long-term warming; (ii) similarly to bryophyte cover, richness decreased under long-term warming, but the decline was smaller than the loss in cover and diversity was not affected; and (iii) deciduous shrub and litter cover had a negative effect on bryophyte cover, but not on bryophyte richness. However, in contrast to what was hypothesized, the negative impacts of warming were greater for the heath community compared to the meadow community.

\section{Changes in species composition in bryophyte communities under long-term warming}

Principal response curve analysis showed that bryophyte species did not all respond to the experimental warming provided by OTCs in the same manner. This is in line with previous findings of both contractions and expansions in bryophyte species in Europe (Bergamini et al. 2009; Désamoré et al. 2012; Hodd et al. 2014). For example, a study on bryophytes using 10521 specimens from biological collections in Switzerland found that 16 species had declined since 1850-1939, while four had increased (Hofmann et al. 2007). In the present study, we found that species composition of bryophytes in the meadow vegetation became more similar over time in the warming and control plots. In contrast, there were significant differences in species composition in the heath vegetation between control and warming plots. The hypothesis that bryophytes in mesic meadow are more vulnerable was not supported by the data. Instead, the results suggested that bryophytes in alpine heath vegetation are more susceptible to warming than those in meadow vegetation, supporting the suggestion that bryophyte communities may be less resistant in drier environments than in wetter habitats (Turetsky et al. 2012). It should be noted that PRC was initially developed for use in experiments such as ecotoxicology, where the control communities remain similar throughout the experiment, whereas the control plots in climate change experiments (i.e. this study) might experience large changes. Thus, while our PRC results show which species contributed to the difference (increase or decrease) between the warmed plots and control plots, it used the control plots as constants and placed them at a 'zero' line. Therefore, if the warming plots remain unchanged through the time and the 


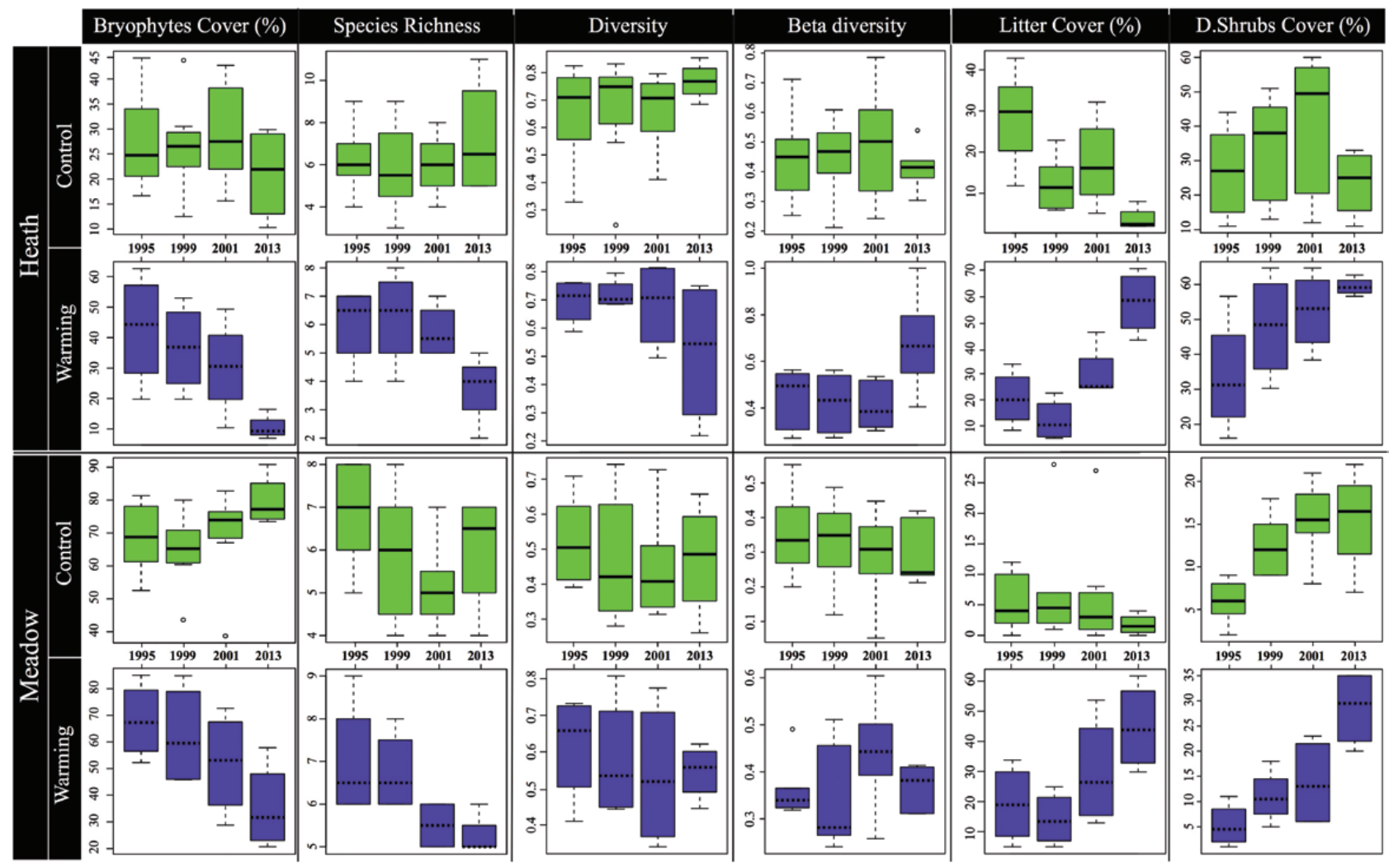

Figure 2. Boxplots showing bryophyte cover, bryophyte richness, bryophyte diversity, bryophyte beta diversity, litter cover and deciduous shrub cover over time in control (green, top row) and warmed (blue, bottom row) plots in heath (top panel) and meadow (bottom panel) vegetation at Latnjajaure, northern Sweden.

control plots experienced compositional changes, the changes in the control plots (or plots experiencing ambient conditions) would appear as changes in the warmed plots. Consequently, it is not possible to know from the PRC whether the changes in species abundance displayed occurred due to changes in the warmed or the control plots. Experimental treatments are usually perceived as the cause of changes, but in natural systems 'control' (ambient) communities may change due to different factors, such as natural warming over the study period (Alatalo et al. 2017a), changes in precipitation between years (Fang et al. 2005), deposition of nutrients (Remke et al. 2009; Maskell et al. 2010) or changes in the communities due to natural succession/ competition, etc. Here, we used ANOSIM and evaluated beta diversity changes to exclude the effects of this potential drawback on our interpretations. With this in mind, the PRCs are still useful in displaying differences between treatments over time and the species contributing to the changes.

The results showed that response patterns of beta diversity differed between sites, with the meadow community being more resistant to warming than the heath, and that plot-scale (i.e. small-scale) features are likely to play an important role in determining the resulting bryophyte communities. A study on alpine bryophyte communities in northern Italy showed that species track specific climate conditions along elevation gradients, leading to the prediction that climate change will increase species turnover of bryophyte communities, rather than leading to species loss (Nascimbene and Spitale 2017). In contrast, a study in the Canadian Rocky mountains found that bryophytes had a wide tolerance to temperature and elevationrelated factors, thus having broader habitats and lower beta diversity along elevation gradients (Lee and La Roi 1979).
At our study site in northern Sweden, the shorter-term (1995-2001) (Alatalo et al. 2015a) and long-term (1995-2013) responses showed contrasting patterns. The latter underscores the importance of maintaining long-term monitoring and experimental studies to better understand community dynamics. Thus, the initial conclusions based on the fact that bryophytes did not show any significant changes failed to predict long-term responses correctly. In a previous study where we analysed bryophyte richness and diversity responses after 5 years of experimental warming and nutrient addition, we only found significant impacts for treatments with nutrient addition in the meadow, and no significant impact of the warming treatments (Jägerbrand et al. 2009). Consequently, the conclusions from our previous and present study clearly demonstrate that bryophyte communities show delayed responses, as shown for vascular plants. Many plant communities have been shown to be resistant to experimental perturbations during the first 10 years, but are increasingly affected thereafter (Komatsu et al. 2019).

\section{Species-specific responses}

Bryophyte species can be expected to differ in their responses to warming, as they differ in their temperature optimum, desiccation tolerance and shading tolerance (Furness and Grime 1982; Glime 2006; Humbert et al. 2007; He et al. 2016). In order to understand why different species showed an increase (P. ciliare and S. capillifolium) or decrease (K. starkei, G. concinnatum, H. splendens and P. alpinum) in the PRCs, we consulted the BRYOATT list for Ellenberg values (light, moisture, nitrogen) (Hill et al. 2007) and broad temperature distribution (Hill and Preston 1998) for the species. This showed that the species with the largest decrease and largest increase in abundance did not 

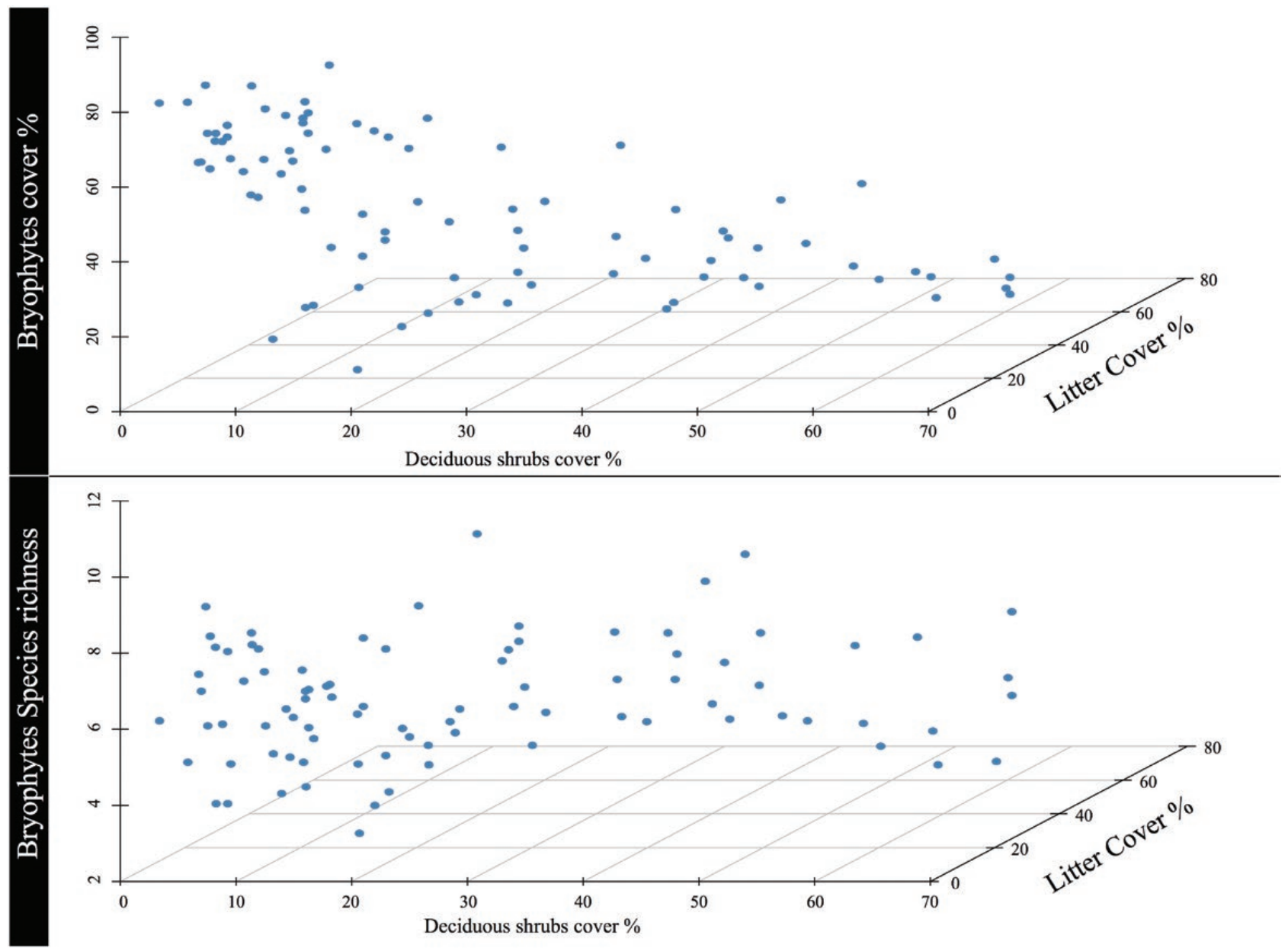

Figure 3. Three-dimensional scatter plots comparing the relationship between bryophyte cover and richness and deciduous shrubs and litter cover at Latnjajaure, northern Sweden.

differ markedly, with similar Ellenberg values for light (6 and 7), moisture (5, except S. capillifolium with 7) and nitrogen (1 and 2) found in the increasing and decreasing groups. Similarly, grouping within Arctic-alpine, sub-Arctic-sub-alpine and more boreal species (Hill and Preston 1998) did not explain the responses. This is line with the results obtained in the Canadian Rocky mountains, where bryophytes were shown to display a wide range of tolerance to elevation- and temperaturecorrelated factors (Lee and La Roi 1979). Therefore, it is likely that the species differ in relative competitive advantage in some other way, such as ability to cope with increasing litter deposition in warmed plots (Rincon 1988).

Impacts of climate change on bryophyte cover, species richness and diversity

As hypothesized, bryophyte cover (in both communities) and richness (heath only) declined under long-term experimental warming, but the species loss was smaller than the decline in cover, indicating a delayed response in species loss. There was no significant effect on Simpson diversity. While the loss of species richness was already evident in the meadow in 2001, the decline in bryophyte cover and species richness increased after 2001 in both communities. In addition, although the decrease in bryophyte richness was larger in the heath, it was more delayed than the decline in the meadow community. This suggests that experimental warming may have caused rare species to become locally extinct earlier in the warmed plots of the meadow community compared with the warmed plots of the heath community. The hypothesis that bryophytes in mesic meadow are more vulnerable was not supported by the data. Instead, the PRC, cover and richness results suggested that bryophytes in alpine heath vegetation are more susceptible to warming than those in meadow vegetation, supporting the suggestion that bryophyte communities may be less resistant in drier environments than in wetter habitats (Turetsky et al. 2012). However, other studies have found polar and alpine bryophytes to be more negatively affected by experimental warming at wetter sites than at drier sites (Elmendorf et al. 2012a). This could be caused by increased drought stress at wetter sites as a result of experimental warming (Davey 1997; Turetsky 2003). For example, in the present experiment, long-warming in the meadow (but not in the heath) caused a decrease in soil moisture (Alatalo et al. 2017b).

Negative responses of bryophytes to experimental warming have also been reported in previous experimental studies (Elmendorf et al. 2012a; Lang et al. 2012; Sistla et al. 2013). Cover richness in the present study began to decline more markedly after 7 years of warming, as also found in other shorter-term studies in Sweden and Tibet (Alatalo et al. 2015a; Sun et al. 2017). However, bryophyte responses to long-term warming are not always negative (Van Wijk et al. 2003; Hudson and Henry 2010; Bokhorst et al. 2016). For example, 15 years of experimental warming resulted in an increase in bryophyte cover in High Arctic 
Canada (Hudson and Henry 2010). While bryophyte cover in our experimentally warmed plots declined in both the meadow and heath community, bryophyte cover tended to increase in the control plots in the meadow community, but not in the heath. This may be because Latnjajaure experienced natural warming of roughly $2{ }^{\circ} \mathrm{C}$ in the period 1993-2013, which may have caused a greater increase in vascular plant canopy in the heath community than in the meadow community (Alatalo et al. 2017a). Bryophytes are generally highly dependent on external water (He et al. 2016) and variations in annual rainfall can therefore potentially affect their photosynthesis and growth (Glime 2006; Jägerbrand et al. 2011). Annual precipitation varied substantially between years in the study period, but 2012 and 2013 did not have the highest or lowest annual precipitation (Alatalo et al. 2017a). Thus, it is unlikely that precipitation was the cause of changes in bryophyte cover in 2013. In addition, it is unlikely that the OTCs prevented colonization by bryophytes from outside the warmed plots, as a previous study in High Arctic Canada found that seed production in a wind-pollinated willow was not reduced by OTCs and that insect visitation was also unaffected (Robinson and Henry 2018). Thus, it is unlikely that the OTCs used in our study had a negative effect on wind-dispersed spores.

\section{Impact of shrubification and plant litter on} bryophyte cover, species richness and diversity

Previous studies have reported an increase in deciduous shrub cover in alpine and Arctic tundra (Jägerbrand et al. 2009; MyersSmith et al. 2011; Vowles et al. 2017; Maliniemi et al. 2018), Hence, we examined the correlation between this group of vascular plants and bryophytes. The increase in deciduous shrubs with warming is in line with previous predictions that increased temperature and nutrient mineralization will increase the productivity of vascular plants, which could have a negative effect on bryophytes (Molau and Alatalo 1998; Van der Wal et al. 2005). Our hypothesis of a negative correlation between deciduous shrub cover and bryophyte cover and richness was only partly supported by the data. While deciduous shrub cover had a negative impact on bryophyte cover, it had no impact on bryophyte richness.

We also examined the relationships between litter cover and bryophyte cover/richness. The results indicated a significant negative correlation between bryophyte cover (but not richness) and litter cover. This difference in the relationship between bryophyte cover and richness with deciduous shrub and litter may be because bryophyte species loss takes a longer time than bryophyte cover decrease. However, the differences in litter cover between control and warmed plots may also be an artefact caused by the constant presence of OTCs preventing litter from being blown away by the wind, and thus artificially increasing the litter cover. Previous studies have shown that bryophyte and lichen cover is negatively correlated with vascular plant canopy (Löbel et al. 2006; Pajunen et al. 2011; Jägerbrand et al. 2012; Alatalo et al. 2017a). Therefore, the widespread shrubification reported in alpine and Arctic tundra (Jägerbrand et al. 2009; MyersSmith et al. 2011; Maliniemi et al. 2018; Myers-Smith and Hik 2018) could potentially have large impacts on cryptogam communities. However, a study using data from Latnjajaure, Sweden, and Toolik Lake, Alaska, found no negative relationship between bryophytes and abundance of vascular plants (Lang et al. 2012). As shrubification of alpine and Arctic tundra is expected to increase due to climate change, the effect of shrub encroachment on bryophytes needs to be monitored more closely in areas experiencing shrubification.

\section{Conclusions}

Climate change is increasing at a more rapid rate than previously predicted, with widespread impacts on Arctic and alpine regions. This study showed that the important, but relatively understudied, Arctic and alpine bryophytes are likely to be adversely affected in the longer term. In this study, the responses to warming were non-linear over time, with negative effects accelerating after 7 years of experimental warming. Bryophyte cover declined more than richness, indicating a more delayed decline in species richness than in abundance. Bryophytes in the meadow community were expected to be more susceptible to warming, but PRC, cover and richness results indicated that the community in the drier heath habitat was more vulnerable. The decline in total bryophyte cover in both the heath and meadow communities was driven by a general decline in multiple species. Many of the most common species did not show any detectable changes, but the cumulative change was significant. Comparing the Ellenberg values for light, moisture and temperature optima of the bryophyte species experiencing the largest increase/ decrease did not explain the different responses. Shrubification and indirect effects of litter (following shrubification) could be important mechanisms behind the decrease in bryophyte cover.

\section{Supporting Information}

The following additional information is available in the online version of this article-

Table S1. Bryophyte species included in the community analysis (cover, richness and diversity).

Figure S1. Relative changes in richness, diversity, beta diversity, bryophyte cover, deciduous shrub cover and litter cover at start (1995), five (1999), seven (2001) and 18 years (2013) of warming treatment in heath and meadow vegetation at Latnjajaure, northern Sweden.

\section{Data Availability}

Data used for analyses are included in the electronic supplementary materials.

\section{Sources of Funding}

This study was supported by Carl Tryggers stiftelse för vetenskaplig forskning and Qatar Petroleum (QUEX-CASQP-RD-18/19) to J.M.A.

\section{Contributions by the Authors}

J.M.A. and U.M. designed the experiment. J.M.A., A.K.J. and U.M. carried out fieldwork. J.M.A., M.B.E. and S.C. carried out data analyses. M.B.E. prepared the figures and tables. J.M.A. and M.B.E. drafted the manuscript. All authors read, commented on and approved the final manuscript.

\section{Conflict of Interest}

None declared.

\section{Acknowledgements}

The authors thank the staff of Abisko Scientific Research Station for their help and hospitality, Matthias Molau, and the reviewers 
for constructive comments that improved the paper. Bruno Welter Giraldes for help with illustration.

\section{Literature Cited}

Alatalo JM, Jägerbrand AK, Chen S, Molau U. 2017a. Responses of lichen communities to 18 years of natural and experimental warming. Annals of Botany 120:159-170.

Alatalo JM, Jägerbrand AK, Juhanson J, Michelsen A, Luptáčik P. 2017b. Impacts of twenty years of experimental warming on soil carbon, nitrogen, moisture and soil mites across alpine/subarctic tundra communities. Scientific Reports 7:44489.

Alatalo JM, Jägerbrand AK, Molau U. 2014a. Climate change and climatic events: community-, functional- and species-level responses of bryophytes and lichens to constant, stepwise, and pulse experimental warming in an alpine tundra. Alpine Botany 124:81-91.

Alatalo JM, Jägerbrand AK, Molau U. 2015a. Testing reliability of short-term responses to predict longer-term responses of bryophytes and lichens to environmental change. Ecological Indicators 58:77-85.

Alatalo JM, Little CJ, Jägerbrand AK, Molau U. 2014b. Dominance hierarchies, diversity and species richness of vascular plants in an alpine meadow: contrasting short and medium term responses to simulated global change. PeerJ 2:e406.

Alatalo JM, Little CJ, Jägerbrand AK, Molau U. 2015b. Vascular plant abundance and diversity in an alpine heath under observed and simulated global change. Scientific Reports 5:10197.

Arft AM, Walker MD, Gurevitch J, Alatalo JM, Bret-Harte MS, Dale M, Diemer M, Gugerli F, Henry GHR, Jones MH, Hollister RD, Jónsdóttir IS, Laine K, Lévesque E, Marion GM, Molau U, Mølgaard P, Nordenhäll U, Raszhivin V, Robinson CH, Starr G, Stenström A, Stenström M, Totland $\varnothing$, Turner PL, Walker LJ, Webber PJ, Welker JM, Wookey PA. 1999. Responses of tundra plants to experimental warming: meta-analysis of the international tundra experiment. Ecological Monographs 69:491-511.

Bahuguna YM, Gairola S, Uniyal PL, Bhatt AB. 2016. Moss flora of Kedarnath Wildlife Sanctuary (KWLS), Garhwal Himalaya, India. Proceedings of the National Academy of Sciences, India Section B: Biological Sciences 86:931-943.

Bates JW, Thompson K, Grime JP. 2005. Effects of simulated longterm climatic change on the bryophytes of a limestone grassland community. Global Change Biology 11:757-769.

Bergamini A, Ungricht S, Hofmann H. 2009. An elevational shift of cryophilous bryophytes in the last century-an effect of climate warming? Diversity and Distributions 15:871-879.

Björk RG, Klemedtsson L, Molau U, Harndorf J, Ödman A, Giesler R. 2007. Linkages between $\mathrm{N}$ turnover and plant community structure in a tundra landscape. Plant and Soil 294:247-261.

Bokhorst S, Convey P, Huiskes A, Aerts R. 2016. Usnea antarctica, an important Antarctic lichen, is vulnerable to aspects of regional environmental change. Polar Biology 39:511-521.

Chapin FI, Shaver G, Giblin A, Nadelhoffer K, Laundre J. 1995. Responses of arctic tundra to experimental and observed changes in climate. Ecology 76:694-711.

Cornelissen JH, Lang SI, Soudzilovskaia NA, During HJ. 2007. Comparative cryptogam ecology: a review of bryophyte and lichen traits that drive biogeochemistry. Annals of Botany 99:987-1001.

Crafford JE, Chown SL. 1991. Comparative nutritional ecology of bryophyte and angiosperm feeders in a sub-Antarctic weevil species complex (Coleoptera: Curculionidae). Ecological Entomology 16:323-329.

Davey MC. 1997. Effects of short-term dehydration and rehydration on photosynthesis and respiration by Antarctic bryophytes. Environmental and Experimental Botany 37:187-198.

Désamoré A, Laenen B, Stech M, Papp B, Hedenäs L, Mateo RG, Vanderpoorten A. 2012. How do temperate bryophytes face the challenge of a changing environment? Lessons from the past and predictions for the future. Global Change Biology 18:2915-2924.

Dumais C, Ropars P, Denis M-P, Dufour-Tremblay G, Boudreau S. 2014. Are low altitude alpine tundra ecosystems under threat? A case study from the Parc National de la Gaspésie, Québec. Environmental Research Letters 9:094001.

During HJ, Van Tooren BF. 1990. Bryophyte interactions with other plants. Botanical Journal of the Linnean Society 104:79-98.
Elmendorf SC, Henry GH, Hollister RD, Alatalo J, Björk RG, Bjorkman AD, Callaghan TV, Collier LS, Cooper EJ, Cornelissen JHC, Day TA, Fosaa AM, Gould WA, Grétarsdóttir J, Harte J, Hermanutz L, Hik DS, Hofgaard A, Jarrad F, Jónsdóttir IS, Keuper F, Klanderud K, Klein JA, Koh S, Kudo G, Lang SI, Loewen V, May J, Mercado J, Michelsen A, Molau U, MyersSmith IH, Oberbauer SF, Pieper S, Post E, Rixen C, Robinson CH, Schmidt NM, Shaver GR, Stenström A, Tolvanen A, Totland $\varnothing$, Troxler T, Wahren C-H, Walker MD, Webber PJ, Welker JM, Philip A, Wookey PA. 2012a. Global assessment of experimental climate warming on tundra vegetation: heterogeneity over space and time. Ecology Letters 15:164-175.

Elmendorf SC, Henry GHR, Hollister RD, Björk RG, Boulanger-Lapointe N, Cooper EJ, Cornelissen JHC, Day TA, Dorrepaal E, Elumeeva TG, Gill M, Gould WA, Harte J, Hik DS, Hofgaard A, Johnson DR, Johnstone JF, Jónsdóttir IS, Jorgenson JC, Klanderud K, Klein JA, Koh S, Kudo G, Lara M, Lévesque E, Magnússon B, May JL, Mercado-Dı JA, Michelsen A, Molau U, Myers-Smith IH, Oberbauer SF, Onipchenko VG, Rixen C, Schmidt NM, Shaver GR, Spasojevic MJ, Pórhallsdóttir PE, Tolvanen A, Troxler T, Tweedie CE, Villareal S, Wahren C-H, Walker X, Webber PJW, Welker JM, Wipf S. 2012b. Plot-scale evidence of tundra vegetation change and links to recent summer warming. Nature Climate Change 2:453-457.

Erfanian MB, Ejtehadi H, Vaezi J, Moazzeni H, Memariani F, FirouzJahantigh M. 2019. Plant community responses to environmentally friendly piste management in northeast Iran. Ecology and Evolution 9:8193-8200.

Fang J, Piao S, Zhou L, He J, Wei F, Myneni RB, Tucker CJ, Tan K. 2005. Precipitation patterns alter growth of temperate vegetation. Geophysical Research Letters 32:L21411.

Furness SB, Grime JP. 1982. Growth rate and temperature responses in bryophytes: II. A comparative study of species of contrasted ecology. Journal of Ecology 70:525-536.

Glime JM. 2006. Bryophyte ecology. Houghton, MI: Michigan Technological University \& International Association of Bryologists.

He X, He KS, Hyvönen J. 2016. Will bryophytes survive in a warming world? Perspectives in Plant Ecology, Evolution and Systematics 19:49-60.

Herbert H, Prins T. 1982. Why are mosses eaten in cold environments only? Oikos 38:374-380.

Hill MO, Preston CD. 1998. The geographical relationships of British and Irish bryophytes. Journal of Bryology 20:127-226.

Hill MO, Preston CD, Bosanquet SDS, Roy DB. 2007. BRYOATT: attributes of British and Irish mosses, liverworts and hornworts. Huntingdon, Cambridgeshire, UK: Centre for Ecology and Hydrology.

Hodd RL, Bourke D, Skeffington MS. 2014. Projected range contractions of European protected oceanic montane plant communities: focus on climate change impacts is essential for their future conservation. PLoS One 9:e95147.

Hodkinson ID, Coulson S, Webb NR, Block W, Strathdee AT, Bale JS. 1994. Feeding studies on Onychiurus arcticus (Tullberg) (Collembola: Onychiuridae) on West Spitsbergen. Polar Biology 14:17-19.

Hofmann H, Urmi E, Bisang I, Muller N, Kuchler M, Schnyder N, Schubiger C. 2007. Retrospective assessment of frequency changes in Swiss bryophytes over the last two centuries. Lindbergia 32:18-32.

Hollister RD, Webber PJ. 2000. Biotic validation of small open-top chambers in a tundra ecosystem. Global Change Biology 6:835-842.

Hudson JMG, Henry GHR. 2010. High Arctic plant community resists 15 years of experimental warming. Journal of Ecology 98:1035-1041.

Humbert L, Gagnon D, Kneeshaw D, Messier C. 2007. A shade tolerance index for common understory species of northeastern North America. Ecological Indicators 7:195-207.

Imada Y, Kato M. 2016. Bryophyte-feeding of Litoleptis (Diptera: Rhagionidae) with descriptions of new species from Japan. Zootaxa 4097:41-58.

IPCC. 2013. Climate change 2013: the physical science basis. Contribution of working Group I to the fifth assessment report of the intergovernmental panel on climate change. Cambridge: Cambridge University Press.

Jägerbrand AK, Alatalo JM, Chrimes D, Molau U. 2009. Plant community responses to 5 years of simulated climate change in meadow and heath ecosystems at a subarctic-alpine site. Oecologia 161:601-610.

Jägerbrand AK, Alatalo JM, Kudo G. 2014. Variation in responses to temperature treatments ex situ of the moss Pleurozium schreberi (Willd. ex Brid.) Mitt. originating from eight altitude sites in Hokkaido, Japan. Journal of Bryology 36:209-2016. 
Jägerbrand AK, Björk RG, Callaghan TV, Seppelt R. 2011. Effects of climate change on tundra bryophytes. In: Tuba Z, Slack NG, Stark LR, eds. Bryophyte ecology and climate change. Cambridge, UK: Cambridge University Press, 211-236.

Jägerbrand AK, Kudo G, Alatalo JM, Molau U. 2012. Effects of neighboring vascular plants on the abundance of bryophytes in different vegetation types. Polar Science 6:200-208.

Jägerbrand AK, Lindblad KEM, Björk RG, Alatalo JM, Molau U. 2006. Bryophyte and lichen diversity under simulated environmental change compared with observed variation in unmanipulated alpine tundra. Biodiversity and Conservation 15:4453-4475.

Jägerbrand AK, Molau U, Alatalo JM. 2003. Responses of bryophytes to simulated environmental change at Latnjajaure, northern Sweden. Journal of Bryology 25:163-168.

Kent M. 2011. Vegetation description and data analysis: a practical approach. Oxford, UK: John Wiley \& Sons.

Klanderud K. 2008. Species-specific responses of an alpine plant community under simulated environmental change. Journal of Vegetation Science 19:363-372.

Klanderud K, Totland $\varnothing$. 2008. Diversity-stability relationships of an alpine plant community under simulated environmental change. Arctic, Antarctic, and Alpine Research 40:679-684.

Komatsu KJ, Avolio ML, Lemoine NP, Isbell F, Grman E, Houseman GR, Koerner SE, Johnson DS, Wilcox KR, Alatalo JM, Anderson JP, Aerts R, Baer SG, Baldwin AH, Bates J, Beierkuhnlein C, Belote RT, Blair J, Bloor JMG, Bohlen PJ, Bork EW, Boughton EH, Bowman WD, Britton AJ, Cahill JF, Chaneton E, Chiariello NR, Cheng J, Collins SL, Cornelissen JHC, Du G, Eskelinen A, Firn J, Foster B, Gough L, Gross K, Hallett LM, Han X, Harmens H, Hovenden MJ, Jagerbrand A, Jentsch A, Kern C, Klanderud K, Knapp AK, Kreyling J, Li W, Luo Y, McCulley RL, McLaren JR, Megonigal JP, Morgan JW, Onipchenko V, Pennings SC, Prevéy JS, Price JN, Reich $\mathrm{PB}$, Robinson CH, Russell FL, Sala OE, Seabloom EW, Smith MD, Soudzilovskaia NA, Souza L, Suding K, Suttle KB, Svejcar T, Tilman D, Tognetti P, Turkington R, White S, Xu Z, Yahdjian L, Yu Q Zhang P, Zhang Y. 2019. Global change effects on plant communities are magnified by time and the number of global change factors imposed. Proceedings of the National Academy of Sciences of the United States of America 116:201819027

Koncz P, Hermanutz L, Marino P, Wheeler J, Cranston B. 2018. Bryophyte community diversities and expected change under a warming climate in contrasting habitats of the Torngat Mountains, Labrador. The Bryologist 121:174-182.

Lang SI, Cornelissen JHC, Hölzer A, ter Braak CJF, Ahrens M, Callaghan TV, Aerts R. 2009. Determinants of cryptogam composition and diversity in Sphagnum-dominated peatlands: the importance of temporal, spatial and functional scales. Journal of Ecology 97:299-310.

Lang SI, Cornelissen JHC, Shaver GR, Ahrens M, Callaghan TV, Molau U, Ter Braak CJF, Hölzer A, Aerts R. 2012. Arctic warming on two continents has consistent negative effects on lichen diversity and mixed effects on bryophyte diversity. Global Change Biology 18:1096-1107.

Lee TD, La Roi GH. 1979. Bryophyte and understory vascular plant beta diversity in relation to moisture and elevation gradients. Vegetatio 40:29-38.

Lindblad KEM, Nyberg R, Molau U. 2006. Generalization of heterogeneous alpine vegetation in air photo-based image classification, Latnjajaure catchment, northern Sweden. Pirineos 161:74-79.

Löbel S, Dengler J, Hobohm C. 2006. Species richness of vascular plants, bryophytes and lichens in dry grasslands: the effects of environment, landscape structure and competition. Folia Geobotanica 41:377-393.

Longton R. 1984. The role of bryophytes in terrestrial ecosystems. The Journal of the Hattori Botanical Laboratory 55:147-163.

Mack MC, Schuur EA, Bret-Harte MS, Shaver GR, Chapin FS. 2004. Ecosystem carbon storage in arctic tundra reduced by long-term nutrient fertilization. Nature 431:440-443.

Maliniemi T, Kapfer J, Saccone P, Skog A, Virtanen R. 2018. Long-term vegetation changes of treeless heath communities in northern Fennoscandia: links to climate change trends and reindeer grazing. Journal of Vegetation Science 29:469-479.

Marion G, Henry GHR, Freckrnan DW, Johnstone J, Jones G, Jones MH, Levesque E, Molau U, Molgaard P, Parsons AN. 1997. Open-top designs for manipulating field temperature in high-latitude ecosystems. Global Change Biology 3:20-32.

Maskell LC, Smart SM, Bullock JM, Thompson K, Stevens CJ. 2010. Nitrogen deposition causes widespread loss of species richness in British habitats. Global Change Biology 16:671-679.

Mateo RG, Broennimann O, Normand S, Petitpierre B, Araújo MB, Svenning JC, Baselga A, Fernández-González F, Gómez-Rubio V, Muñoz J, Suarez GM, Luoto M, Guisan A, Vanderpoorten A. 2016. The mossy north: an inverse latitudinal diversity gradient in European bryophytes. Scientific Reports 6:25546.

Matveyeva N, Chernov Y. 2000. Biodiversity of terrestrial ecosystems. In: Nuttall M, Callaghan TV, eds. The Arctic: environment, people, policy. Reading, UK: Harwood Academic Publishers, 233-273.

May JL, Hollister RD. 2012. Validation of a simplified point frame method to detect change in tundra vegetation. Polar Biology 35:1815-1823.

Molau U, Alatalo JM. 1998. Responses of subarctic-alpine plant communities to simulated environmental change: biodiversity of bryophytes, lichens, and vascular plants. Ambio 27:322-329.

Molau U, Nordenhäll U, Eriksen B. 2005. Onset of flowering and climate variability in an alpine landscape: a 10-year study from Swedish Lapland. American Journal of Botany 92:422-431.

Mouillot D, Lepretre A. 1999. A comparison of species diversity estimators. Population Ecology 41:203-215.

Myers-Smith IH, Forbes BC, Wilmking M, Hallinger M, Lantz T, Blok D, Sass UGW. 2011. Shrub expansion in tundra ecosystems: dynamics, impacts and research priorities. Environmental Research Letters 6:045509.

Myers-Smith IH, Hik DS. 2018. Climate warming as a driver of tundra shrubline advance. Journal of Ecology 106:547-560.

Nascimbene J, Spitale D. 2017. Patterns of beta-diversity along elevational gradients inform epiphyte conservation in alpine forests under a climate change scenario. Biological Conservation 216:26-32.

Oechel WC, Sveinbjörnsson B. 1978. Primary production processes in arctic bryophytes at Barrow, Alaska. In: Tieszen LL, ed. Vegetation and production ecology of an Alaskan arctic tundra. New York, NY: SpringerVerlag, 269-298.

Oksanen J, Blanchet FG, Friendly M, Kindt R, Legendre P, McGlinn D, Minchin PR, OHara RB, Simpson GL, Solymos P, Stevens MHH, Szoecs E, Wagner H. 2017. Vegan: community ecology package 2017. R package version 2.4-4. https://CRAN.R-project.org/package=vegan

Pajunen A, Oksanen J, Virtanen R. 2011. Impact of shrub canopies on understorey vegetation in western Eurasian tundra. Journal of Vegetation Science 22:837-846.

Polunin N. 1951. The real arctic: suggestions for its delimitation, subdivision, and characterization. Journal of Ecology 39:308-315.

Press M, Potter J, Burke M, Callaghan T, Lee J. 1998. Responses of a subarctic dwarf shrub heath community to simulated environmental change. Journal of Ecology 86:315-327.

R Core Team. 2019. R: a language and environment for statistical computing. Vienna, Austria: R Foundation for Statistical Computing.

Remke E, Brouwer E, Kooijman A, Blindow I, Esselink H, Roelofs JG. 2009. Even low to medium nitrogen deposition impacts vegetation of dry, coastal dunes around the Baltic Sea. Environmental Pollution 157:792-800.

Rincon E. 1988. The effect of herbaceous litter on bryophyte growth. Journal of Bryology 15:209-217.

Robinson SV, Henry GH. 2018. High Arctic plants show independent responses to pollination and experimental warming. Botany 96:385-396

Simpson EH. 1949. Measurement of diversity. Nature 163:688.

Sistla SA, Moore JC, Simpson RT, Gough L, Shaver GR, Schimel JP. 2013. Long-term warming restructures Arctic tundra without changing net soil carbon storage. Nature 497:615-618.

Smith RM, Young MR, Marquiss M. 2001. Bryophyte use by an insect herbivore: does the crane-fly Tipula montana select food to maximise growth? Ecological Entomology 26:83-90.

Sun S-Q Wang G-X, Chang SX, Bhatti JS, Tian W-L, Luo J. 2017. Warming and nitrogen addition effects on bryophytes are species- and plant community-specific on the eastern slope of the Tibetan Plateau. Journal of Vegetation Science 28:128-138. 
Sun SQ, Wu YH, Wang GX, Zhou J, Yu D, Bing HJ, Luo J. 2013. Bryophyte species richness and composition along an altitudinal gradient in Gongga Mountain, China. PLoS One 8:e58131.

The Plant List 1.1. 2013. http://www.theplantlist.org/1.1/cite/ (1 October 2020).

Turetsky M. 2003. The role of bryophytes in carbon and nitrogen cycling. The Bryologist 106:395-409.

Turetsky MR, Bond-Lamberty B, Euskirchen E, Talbot J, Frolking S, McGuire AD, Tuittila ES. 2012. The resilience and functional role of moss in boreal and arctic ecosystems. The New Phytologist 196:49-67.

USDA, NRCS. 2020. The PLANTS database. https://plants.sc.egov.usda.gov/ java/ (28 September 2020).

van den Brink PJ, den Besten PJ, bij de Vaate A, ter Braak CJ. 2009. Principal response curves technique for the analysis of multivariate biomonitoring time series. Environmental Monitoring and Assessment 152:271-281.

Van der Wal R, Pearce IS, Brooker RW. 2005. Mosses and the struggle for light in a nitrogen-polluted world. Oecologia 142:159-168.

Van Wijk MT, Clemmensen KE, Shaver GR, Williams M, Callaghans TV, Chapin FS, Cornelissen JHC, Gough L, Hobbie SE, Jonasson S, Lees JA, Michelsen A, Press MC, Richardsons SJ, Rueth H. 2003. Long-term ecosystem level experiments at Toolik Lake, Alaska, and at Abisko, Northern Sweden: generalizations and differences in ecosystem and plant type responses to global change. Global Change Biology 10:105-123.

Vowles T, Björk RG. 2019. Implications of evergreen shrub expansion in the Arctic. Journal of Ecology 107:650-655.

Vowles T, Gunnarsson B, Molau U, Hickler T, Klemedtsson L, Björk RG. 2017. Expansion of deciduous tall shrubs but not evergreen dwarf shrubs inhibited by reindeer in Scandes mountain range. The Journal of Ecology 105:1547-1561.

Wahren C-HA, Walker MD, Bret-Harte MS. 2005. Vegetation responses in Alaskan arctic tundra after 8 years of a summer warming and winter snow manipulation experiment. Global Change Biology 11:537-552.

Walker MD. 1996. Community baseline measurements for ITEX studies. In: Molau U, Miolgaard P, eds. ITEX manual, 2nd edn. Copenhagen, Denmark: Danish Polar Centre, 39-41.

Walker MD, Wahren CH, Hollister RD, Henry GH, Ahlquist LE, Alatalo JM, Bret-Harte MS, Calef MP, Callaghan TV, Carroll AB, Epstein HE, Jónsdóttir IS, Klein JA, Magnússon B, Molau U, Oberbauer SF, Rewa SP, Robinson CH, Shaver GR, Suding KN, Thompson CC, Tolvanen A, Totland $\varnothing$, Turner PL, Tweedie CE, Webber PJ, Wookey PA. 2006. Plant community responses to experimental warming across the tundra biome. Proceedings of the National Academy of Sciences of the United States of America 103:1342-1346.

Wheeler JA, Cortés AJ, Sedlacek J, van Kleunen M, Bossdorf O. 2016. The snow and the willows: earlier spring snowmelt reduces performance in the low-lying alpine shrub Salix herbacea. Journal of Ecology 104:1041-1050.

Wickham H. 2009. ggplot2: elegant graphics for data analysis. New York, NY: Springer-Verlag.

Wielgolaski, FE. 1972. Vegetation types and primary production in tundra. In: Wielgolaski FE, Rosswall, T. eds. Tundra Biome, Proceedings IV. International Meeting on the Biological Production of Tundra, Leningrad 1971, Stockholm, SE: Tundra Biome Steering Committee, 9-34.

Zhang Y, Wang W, Zhu J. 2016. Interactions between warming and soil moisture increase overlap in reproductive phenology among species in an alpine meadow. Biology Letters 12:20150749. 